Minireview

\title{
Mechanisms of Actions of Sodium Hypochlorite in Cleaning and Disinfection Processes
}

\author{
SATOSHI FUKUZAKI* \\ Industrial Technology Center of Okayama Prefecture, \\ 5301 Haga, Okayama 701-1296, Japan
}

Received 23 August 2006/Accepted 13 October 2006

\begin{abstract}
Sodium hypochlorite $(\mathrm{NaOCl})$ is the most widely used disinfectant in the food industry despite the increasing availability of other disinfectants. Sodium hypochlorite fulfills many requirements as the ideal disinfectant and furthermore it has an excellent cleaning action. The effectiveness of sodium hypochlorite in the cleaning and disinfection processes depends on the concentration of available chlorine and the $\mathrm{pH}$ of the solution. Hypochlorous acid $(\mathrm{HOCl})$ is a weak acid and dissociates to the hypochlorite ion $\left({ }^{-} \mathrm{OCl}\right)$ and proton $\left(\mathrm{H}^{+}\right)$depending on the solution $\mathrm{pH}$. It is generally believed that $\mathrm{HOCl}$ is the active species in the germicidal action, whereas the concentration of ${ }^{-} \mathrm{OCl}$ is a key factor determining the cleaning efficiency. This implies that the optimal pH region of the germicidal activity of sodium hypochlorite differs from that of its cleaning activity. This paper describes the theory and practice of the cleaning and disinfecting operations based on the use of sodium hypochlorite solution.
\end{abstract}

Key words : Sodium hypochlorite/Cleaning action/Germicidal activity/Strong electrophile/ Electrolyzed water.

\section{INTRODUCTION}

Nowadays, cleaning and disinfecting operations have been reconfirmed as the fundamental procedures to sustain hygienic conditions in the food industry setting. The main objects to be cleaned and disinfected are the processing equipment, products or food ingredients, packaging materials, and worker's hands and fingers. The cleanliness of all the product-contact surfaces is one of the most important factors to prevent secondary contamination and to produce safe and wholesome products. Cleaning and disinfection are related complementarily to each other, and are performed as a separate or combined operation. The process of cleaning should precede that of disinfection because it is far easier to disinfect a surface unsoiled with organic matter than a soiled surface. In a word, the role of cleaning as a process

${ }^{*}$ Corresponding author. Tel : +81-86-286-9600, Fax : +8186-286-9630. preceding disinfection is to reduce the load of the disinfection process by removing as much soil as possible and by decreasing the number of microbes before they propagate.

At present, sodium hypochlorite $(\mathrm{NaOCl})$ is the most widely used disinfectant in the food industry. Although alcohol, quaternary ammonium compounds, ozone, peracetic acid, hydrogen peroxide, and organic acids are also utilized to reduce microbial populations, the effectiveness of those chemicals has been always examined in comparison with that of sodium hypochlorite. Some advantages and disadvantages of sodium hypochlorite are summarized in Table 1. The advantages of sodium hypochlorite are that it fulfills many requirements of the ideal disinfectant (Rutala and Weber, 1997) and has an excellent cleaning action; furthermore, it is easily combined with some other cleaning elements and detergents. Actually in many food-manufacturing factories, the removal of the organic soils (cleaning) and control of microbes (disinfection) are performed with sodium hypochlorite in a single process. However, the 
TABLE 1. Characteristics of sodium hypochlorite solution as the ideal disinfectant.

\begin{tabular}{|c|c|}
\hline Advantages & $\begin{array}{l}\text { Broad antimicrobial spectrum } \\
\text { Rapid bactericidal action } \\
\text { Reasonable persistence in treated potable } \\
\text { water } \\
\text { Solubility in water; Ease of use } \\
\text { Relative stability in conc. and dil. solutions } \\
\text { Relative nontoxicity to humans at use con- } \\
\text { centrations } \\
\text { Reduced to chloride ion as a result of oxi- } \\
\text { dizing action } \\
\text { Colorless; Nonflammability; Nonstaining; } \\
\text { Low cost } \\
\text { Actions of cleaning, deodorizing, and } \\
\text { bleaching }\end{array}$ \\
\hline Disadvantages & $\begin{array}{l}\text { Irritation to mucous membranes } \\
\text { Evolution of toxic chlorine gas when } \\
\text { mixed with acid } \\
\text { Odor when used in conc. solution } \\
\text { Decreased efficacy in the presence of or- } \\
\text { ganic loads } \\
\text { Deleterious effects on some metals } \\
\text { High surface tension }\end{array}$ \\
\hline
\end{tabular}

mechanisms of sodium hypochlorite actions in cleaning and disinfection processes are originally different from each other. It is dangerous to misunderstand the action of sodium hypochlorite or to use it inappropriately because the effectiveness of its performance can be overestimated. To perform cleaning and disinfecting operations effectively, it is necessary to understand both the chemical properties of sodium hypochlorite and the mechanisms by which soils are removed and microbes are killed.

In this article, I intend to review the mechanisms of the actions of hypochlorous acid, the hypochlorite ion, and hydroxide ion, which are the principal ingredients of a sodium hypochlorite solution, in cleaning and disinfecting operations. In addition, the basic properties of electrolyzed water and weak acidic hypochlorite solution (diluted solution compounded with sodium hypochlorite and acid solution) and their applications in the disinfection process are also described.

\section{BASIC PROPERTIES}

In industrial plants, sodium hypochlorite is manufactured by the absorption of gaseous chlorine in sodium hydroxide solution (eq. 1):

$$
\mathrm{Cl}_{2}+2 \mathrm{NaOH} \rightleftharpoons \mathrm{NaOCl}+\mathrm{NaCl}+\mathrm{H}_{2} \mathrm{O} \text {. }
$$

The principal ingredients of a concentrated sodium hypochlorite solution are hypochlorite and sodium hydroxide. Most common commercial products of sodium hypochlorite are strong base solutions $(\mathrm{pH}$ : 12.5 to 13.5) containing 5 to $12 \%$ of available chlorine (AC). $\mathrm{NaCl}$ formed in eq. 1 is eliminated adequately from the $\mathrm{NaOCl}$ product. It is desirable to store sodium hypochlorite solution under dark and cool conditions because it is unstable when exposed to ultraviolet irradiation.

\section{Oxidizing reaction}

Both hypochlorous acid $(\mathrm{HOCl})$ and the hypochlorite ion $\left({ }^{-} \mathrm{OCl}\right)$ are strong oxidizing agents. $\mathrm{HOCl}$ and ${ }^{-} \mathrm{OCl}$ have been reported to react with a wide variety of biological molecules such as proteins (Hawkins and Davies, 1998 and 1999; Hazell et al., 1993 and 1994), amino acids (Nightingale et al., 2000), peptides (Heinecke et al., 1993), lipids (Spickett et al., 2000), and DNA (Prutz, 1998) at physiological $\mathrm{pH}$ conditions. The $\mathrm{Cl}$ atom in $\mathrm{HOCl}$ and ${ }^{-} \mathrm{OCl}$ behaves as $\mathrm{Cl}^{+}$, a strong electrophile, and combines with a pair of electrons in parts of the substrate that have high electron densities (Wojtowicz, 1979). Among biological molecules, the $\mathrm{C}=\mathrm{C}$ double bond, peptide bond (amide bond), amino groups, and thiol groups are susceptible to the electrophilic attack of $\mathrm{Cl}^{+}$(Nightingale et al., 2000; Pereira et al., 1973; Winterbourn and Brennan, 1997). The $\mathrm{Cl}$ atom is reduced to the chloride ion $\left(\mathrm{Cl}^{-}\right)$as it accepts two electrons. The standard electrode potentials for the reduction of $\mathrm{HOCl}$ and ${ }^{-} \mathrm{OCl}$ are given below (Weast, 1988):

$$
\begin{aligned}
& \mathrm{HOCl}+\mathrm{H}^{+}+2 \mathrm{e}^{-} \rightleftharpoons \mathrm{Cl}^{-}+\mathrm{H}_{2} \mathrm{O} \\
& E_{0}=1.48 \mathrm{~V} \\
& -\mathrm{OCl}+\mathrm{H}_{2} \mathrm{O}+2 \mathrm{e}^{-} \rightleftharpoons \mathrm{Cl}^{-}+2^{-} \mathrm{OH} \\
& E_{0}=0.81 \mathrm{~V} .
\end{aligned}
$$

\section{Dissociation and equilibrium in aqueous solution}

Hypochlorous acid $(\mathrm{HOCl})$ is a weak acid ( $\mathrm{pK}$ $=7.5,25^{\circ} \mathrm{C}$ ) in aqueous solution (Morris, 1966a) and it dissociates readily to ${ }^{-} \mathrm{OCl}$ and $\mathrm{H}^{+}$depending on $\mathrm{pH}$ (eq. 4). Figure 1 shows the variation in the percentage of $\mathrm{HOCl}$ as a function of $\mathrm{pH}$. In general, the $\mathrm{pH}$ of sodium hypochlorite solutions diluted to commonly used concentrations at 50 to $200 \mathrm{mg} \mathrm{AC/L}$ ranged between 8.5 to 10 . In this $\mathrm{pH}$ region, most of the chlorine exists as ${ }^{-} \mathrm{OCl}$. As the $\mathrm{pH}$ of sodium hypochlorite solution decreases to the weak acidic $\mathrm{pH}$ region between 4 and $6, \mathrm{HOCl}$ becomes the predominant species. When the $\mathrm{pH}$ is further lowered to less than $4, \mathrm{HOCl}$ is gradually converted to $\mathrm{Cl}_{2}$ (eq. 5). The shift in the equilibrium of eq. 5 to the right is affected not only by $\mathrm{H}^{+}$concentration but also by $\mathrm{Cl}^{-}$ concentration. The $\mathrm{pHs}$ at which $\mathrm{Cl}_{2}$ begins to 


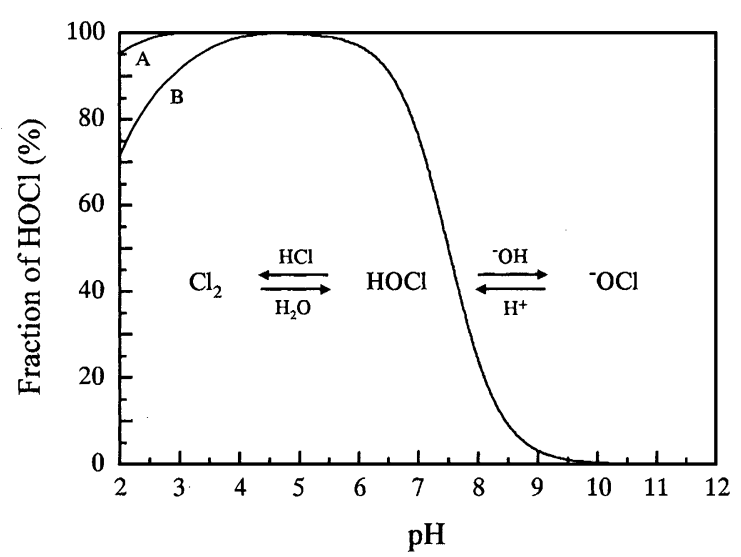

FIG. 1. Distribution of $\mathrm{HOCl}$ in aqueous solution as a function of $\mathrm{pH}$. Curve for $\mathrm{HOCl}-{ }^{-} \mathrm{OCl}$ equilibrium was derived from the calculation by using $p K_{a}$ of 7.5. Curves $A$ and $B$ are the hypothetical curves in the absence and presence of additional $100 \mathrm{mM} \mathrm{NaCl}$, respectively.

generate are approximately 2.8 and 4.5 in the absence and presence of additional $100 \mathrm{mM} \mathrm{NaCl}$, respectively (Iwasawa et al., 2004), as depicted by curves $A$ and $B$ in Fig. 1.

$$
\begin{aligned}
& \mathrm{HOCl} \rightleftharpoons{ }^{-} \mathrm{OCl}+\mathrm{H}^{+} \\
& \mathrm{HOCl}+\mathrm{H}^{+}+\mathrm{Cl}^{-} \rightleftharpoons \mathrm{Cl}_{2}(\mathrm{aq})+\mathrm{H}_{2} \mathrm{O}
\end{aligned}
$$

Thus, in aqueous solution chlorine exists in three different forms, i.e., $\mathrm{Cl}_{2}, \mathrm{HOCl}$, and ${ }^{-} \mathrm{OCl}$, which are called free available chlorine or free residual chlorine. The solubility of $\mathrm{Cl}_{2}$ (aq) in water is very low and therefore $\mathrm{Cl}_{2}$ (aq) readily escapes from the solution. Also, in the neutral $\mathrm{pH}$ region (6.5 to 7.5), undissociated $\mathrm{HOCl}$ tends to be decomposed at a relatively high rate (Adam et al., 1992) and its concentration decreases gradually during the storage period. On the other hand, dissociated ${ }^{-} \mathrm{OCl}$ is more stable in alkaline water, especially at $\mathrm{pHs}$ above 10 , and $\mathrm{AC}$ concentration is almost constant even after a 6-month storage (Siqueira, 2000).

Once free chlorine species reacts with ammonia or $\mathrm{N}$-organo compounds to form monochloramine, dichloramine, and trichloramine or a variety of organo- $N$-chloro compounds, the term used is either combined chlorine, combined residual chlorine, or combined available chlorine. The free and combined available chlorine in water are collectively described as total residual (available) chlorine.

\section{MECHANISM OF THE GERMICIDAL ACTION}

Sodium hypochlorite has a broad antimicrobial spectrum. The germicidal activity of a diluted sodium hypochlorite solution depends on the concentration of $\mathrm{HOCl}$ but not on the total $\mathrm{AC}$ concentration (Brazis et al., 1958, Charlton and Levine, 1935; Dantec, et al., 2002; Sagripanti and Bonifacino, 1996). This is attributed to the penetration of $\mathrm{HOCl}$ into the microbial cell across the cell wall and membrane. It is believed that the mechanism of the germicidal activity of $\mathrm{HOCl}$ or ${ }^{-} \mathrm{OCl}$ is due to the inhibition of enzyme activity essential for the growth, damage to the membrane and DNA, and perhaps an injury to membrane transport capacity although it has not been fully elucidated. $\mathrm{HOCl}$ stress is also suggested to generate common deleterious oxidative species which can damage cellular components (Dunkan and Touati, 1996; Dukan et al., 1999). On the other hand, the germicidal activity of a concentrated sodium hypochlorite solution is based on its high $\mathrm{pH}$ ( ${ }^{-} \mathrm{OH}$ action) and ${ }^{-} \mathrm{OCl}$ oxidation (Estrela et al., 2002).

\section{Membrane permeability and germicidal activity}

A model for the germicidal actions of $\mathrm{HOCl}$ and - $\mathrm{OCl}$ based on their ability to penetrate into the mi-

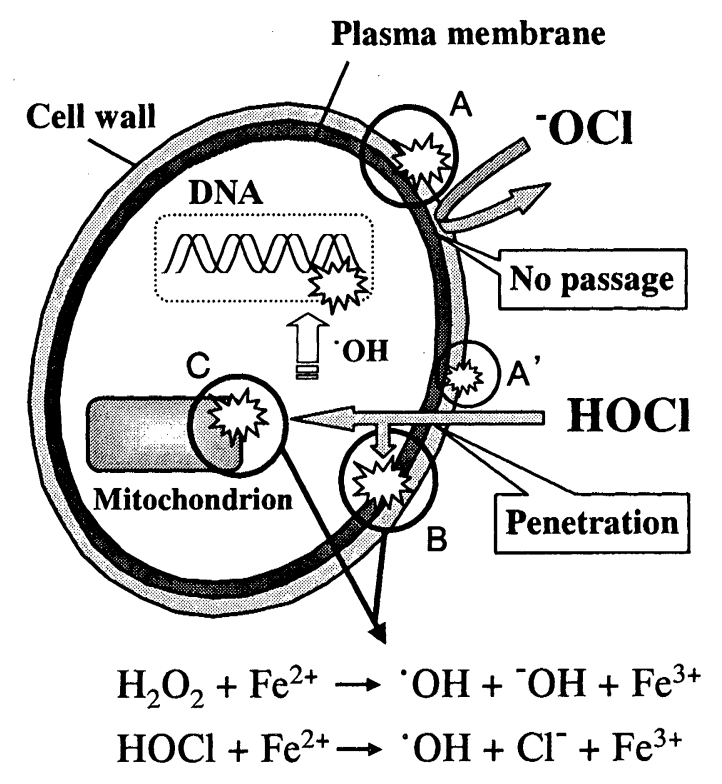

FIG. 2. A model illustrating the mechanisms of the germicidal actions of $\mathrm{HOCl}$ and ${ }^{-} \mathrm{OCl}$ based on their ability to penetrate the membrane into the microbial cell. Ionized ${ }^{-} \mathrm{OCl}$ has a poor germicidal activity because of its inability to diffuse through microbial I plasma membrane, and it exerts an oxidizing action only from outside of the cell (circle A). $\mathrm{HOCl}$ can penetrate the lipid bilayer in the plasma membrane by passive diffusion due to its electrical neutrality. $\mathrm{HOCl}$ can attack the microbial cell both from the outside (circles $A^{\prime}$ ) and inside the cell (circles $\mathrm{B}$ and $\mathrm{C}$ ), which is responsible for the potent germicidal activity of $\mathrm{HOCl}$. 
crobial cell is shown in Fig. 2. This model explains that the germicidal activity is governed by the abilities of $\mathrm{HOCl}$ and ${ }^{-} \mathrm{OCl}$ to diffuse through the microbial cell membrane. Basically, ionized ${ }^{-} \mathrm{OCl}$ is not able to penetrate the microbial cell membrane because of the existence of the lipid bilayer, a hydrophobic layer, of the plasma membrane. Occasionally, some structures of the microbial cell wall also protect the cell from - $\mathrm{OCl}$ penetration. Mycobacteria and corynebacteria possess a peculiar cell wall structure in which the peptidoglycan is covalently linked to mycolic acids, consisting of long fatty acids up to 90 carbon atoms. The mycolic acids represent a hydrophobic barrier to ${ }^{-} \mathrm{OCl}$ entry. Therefore, ${ }^{-} \mathrm{OCl}$ exerts an oxidizing action only form outside the cell (circle $A$ ). In the first step of disinfection by ${ }^{-} \mathrm{OCl}$, the rupture or disintegration of microbial cell wall and membrane appears to occur, and then ${ }^{-} \mathrm{OCl}$ would inactivate functional proteins localized in the plasma membrane. This is responsible for the poor germicidal activity of ${ }^{-} \mathrm{OCl}$. On the other hand, $\mathrm{HOCl}$ can penetrate the lipid bilayer of the plasma membrane by passive diffusion. Apparently, the germicidal activity of sodium hypochlorite is a direct function of the $\mathrm{HOCl}$ concentration. The penetration of $\mathrm{HOCl}$ is due to its electrical neutrality and to its modest molecular size being comparable to that of water. This is true of neutral and small molecules such as $\mathrm{H}_{2} \mathrm{O}_{2}$. As a result, $\mathrm{HOCl}$ can attack the microbial cell not only from outside the cell (circle A') but also from inside the cell (circles B and $C$ ), thereby accelerating the inactivation rate and enhancing the germicidal activity.

Studies on the inactivation of microorganisms by disinfectants indicate that the disinfectant concentration and contact time are the two key variables determining the efficiency of disinfection. The most commonly used model has been derived from the modified Chick-Watson law (Chick, 1908; Watson, 1908):

$$
\log \left(N / N_{0}\right)=-k C T
$$

where $N_{0}$ is the initial number of microorganisms, $N$ is the number of surviving microorganisms at the contact time $T, C$ is the disinfectant concentration, and $k$ is the lethality coefficient (inactivation rate constant) of the microorganism. It has been generally observed that the inactivation of microorganisms follows firstorder kinetics with regard to the $C \times T$ value. Therefore, the $C \times T$ value is commonly used as a unit of germicidal activity that will achieve, for example, 99 to $99.99 \%$ inactivation of the microorganisms. It has been reported that based on a $C \times T$ concept, $\mathrm{HOCl}$ is 80 times more effective a disinfectant to Escherichia coli (Morris, 1966b) and 40 times more effective a disinfectant to Pseudomonas spp.dominating heterotrophic bacteria than ${ }^{-} \mathrm{OCl}$ (LeChevallier et al., 1988). In general, vegetative bacteria are easily inactivated by disinfectants including chlorine, but bacterial spores are highly resistant to chemical disinfectants (Russell, 1990). It is likely that the penetration of disinfectant into the spores may be a major rare-limiting factor, causing a large difference between the disinfection efficiencies of $\mathrm{HOCl}$ and ${ }^{-} \mathrm{OCl}$. It has been reported that $\mathrm{HOCl}$ is approximately 100 times (Brazis, 1958) and 1,000 times (Nebel, 1981) more germicidal to Bacillus spp. spores than ${ }^{-} \mathrm{OCl}$. Penetration of $\mathrm{HOCl}^{-} \mathrm{OCl}$ is also attained in the presence of methanol and other alcohols, resulting in powerful sporicidal activity (Coates and Death, 1978; Death and Coates, 1979). In addition, chlorine disinfection is more efficient at higher temperatures. Studies on the effect of temperature on the inactivation by sodium hypochlorite have shown that the rate constant for the inactivation of Bacillus subtilis spores has an Arrhenius-type temperature dependence (Dantec, et al., 2002; Page, 2003; Sagripanti and Bonifacino, 1996).

The behavior of $\mathrm{HOCl}$, a weak acid, in membrane penetration is also the same as those of undissociated organic acids used as antimicrobial acidulous agents to preserve foods. The antimicrobial action of organic acids is due not only to $\mathrm{pH}$ reduction in the environment but also to the entry of organic acids in undissociated forms into the cell, causing a drop of intracellular $\mathrm{pH}$ by the dissociation of protons from the acid (Fukuzaki et al., 1990). The excess protons have to be extruded out from the cell to maintain a functional proton gradient $(\Delta \mathrm{pH})$. The extrusion of protons by the ATPase would require the hydrolysis of ATP, meaning a decrease in ATP availability for the growth and metabolism of the organisms. Consequently, organic acids might act as uncouplers of the membrane proton gradient and hence of oxidative phosphorylation (Herrero et al., 1985). In the case of $\mathrm{HOCl}$, however, the principale germicidal activity is attributed to the oxidizing action of $\mathrm{HOCl}$ rather than to the reduction of the $\Delta \mathrm{pH}$ or ATP availability of the cell.

\section{$\mathrm{HOCl}$-induced damage}

Molecules that have highly nucleophilic sites are supposed to react rapidly with $\mathrm{HOCl}$ (or ${ }^{-} \mathrm{OCl}$ ). Among the cellular components, these include porphyrins and hemes, ferredoxin-like iron-sulfur centers, purine and pyrimidine bases, conjugated polyenes, amines, amino acids, and sulfhydryl groups (Albrich et al., 1981). The oxidation of these components by $\mathrm{HOCl}$ results in the loss of physiological 
functions. During $\mathrm{HOCl}$ stress for $E$. coli, loss of catalytic function of sulfhydryl enzymes and decrease in antioxidants such as glutathione have been suggested to be the bactericidal events (Albrich et al., 1981; Dukan et al., 1999; Thomas, 1979). HOCl has also been found to disrupt oxidative phosphorylation (Barrette et al., 1989), metabolic pathways involved in ATP utilization or generation (Barrette et al., 1987), and other membrane-associated activities (Champer and McFeters, 1979). Furthermore, HOCI can cause DNA damage resulting from the formation of chlorinated derivatives of nucleotide bases (Dunkan and Touati, 1996; McKenna and Davies, 1988). At present, it can be summarized that the primary effect of $\mathrm{HOCl}$ is either or both (i) the oxidation of sulfhydryl (SH) groups of essential enzymes and antioxidants and (ii) deleterious effects on DNA synthesis.

\section{Involvement of reactive oxygen species}

Under the stress of $\mathrm{HOCl}$, the possible involvement of reactive oxygen species (ROS) generated in microbial cells has been suggested (Dunkan and Touati, 1996; Dukan et al., 1999). Aerobic organisms must deal with ROS such as superoxide anions $\left(\mathrm{O}_{2}^{-}\right)$, hydrogen peroxide $\left(\mathrm{H}_{2} \mathrm{O}_{2}\right)$, and hydroxyl radicals $(\cdot \mathrm{OH})$ that are generated from sequential univalent reductions of oxygen during oxidative phosphorylation:

$$
\mathrm{O}_{2} \rightarrow \mathrm{O}_{2}^{-} \rightarrow \mathrm{H}_{2} \mathrm{O}_{2} \rightarrow \cdot \mathrm{OH} \rightarrow \mathrm{H}_{2} \mathrm{O} \text {. }
$$

Oxidative phosphorylation is localized in the mitochondrial inner membrane of eukaryotic cells (circle C in Fig. 2) or in the plasma membrane of prokaryotic cells (circle B in Fig. 2). Cells are equipped with several defenses including antioxidants such as glutathione, and enzymes including catalases, peroxidases, and superoxide dismutases that are involved in eq. 7. If antioxidants are exhausted or the activities of these enzymes are once inactivated by $\mathrm{HOCl}, \mathrm{O}_{2}^{-}$and $\mathrm{H}_{2} \mathrm{O}_{2}$ would accumulate. $\mathrm{H}_{2} \mathrm{O}_{2}$ can readily diffuse into the cytoplasm through the mitochondrial inner membrane or plasma membrane. On the other hand, free iron is found to be released from microbial iron centers, i.e., heme and non-heme iron proteins, during exposure to $\mathrm{HOCl}$ (Rusen and Klebanoff, 1982). This can lead to the production of highly reactive $\cdot \mathrm{OH}$ via the Fenton reaction:

$$
\mathrm{H}_{2} \mathrm{O}_{2}+\mathrm{Fe}^{2+} \rightarrow \cdot \mathrm{OH}+{ }^{-} \mathrm{OH}+\mathrm{Fe}^{3+} .
$$

The formed $\mathrm{Fe}^{3+}$ is reduced to $\mathrm{Fe}^{2+}$ by $\mathrm{O}_{2}^{-}$(HarberWeiss reaction). Besides the Fenton reaction, it has been reported that the reaction between $\mathrm{HOCl}$ and iron is also a potential source of ${ }^{\circ} \mathrm{OH}$ in activated neutrophils (Folkes et al., 1995):

$$
\mathrm{HOCl}+\mathrm{Fe}^{2+} \rightarrow \mathrm{OH}+\mathrm{Cl}^{-}+\mathrm{Fe}^{3+} .
$$

Thus, it is likely that the endogenously formed $\cdot \mathrm{OH}$ is also responsible for the potent germicidal activity of $\mathrm{HOCl}$.

\section{A concentrated $\mathrm{NaOCl}$ solution}

A concentrated sodium hypochlorite solution is a strong base solution due to the presence of $\mathrm{NaOH}$, i.e., ${ }^{-} \mathrm{OH}$. High concentrations of ${ }^{-} \mathrm{OH}$, i.e., $\mathrm{pH}>12.5$, can alter the integrity of the cell wall and plasma membrane through degradation of constituents such as mucopolysaccharides, proteins, phospholipids or unsaturated fatty acids of the plasma membrane (Estrela et al., 2002). In this $\mathrm{pH}$ region, ${ }^{-} \mathrm{OH}$ may act primarily as an active antimicrobial agent. In addition, - $\mathrm{OCl}$ inactivates the essential enzymes via the oxidation of $\mathrm{SH}$ groups and the chloramination of amino groups, resulting in the dysfunction of membrane ac tivity. Mixtures of sodium hypochlorite at $200 \mathrm{mg}$ $\mathrm{AC} / \mathrm{L}$ with 1.5 to $4 \% \mathrm{NaOH}$ are much more rapidly sporicidal than either $\mathrm{NaOH}$ or sodium hypochlorite used alone (Cousins and Allan, 1967). This is due to the fact that high concentrations of ${ }^{-} \mathrm{OH}$ can dissolve the spore coat that consists mainly of proteins, thereby increasing - $\mathrm{OCl}$ penetration or inducing spore lysis.

\section{Effect of organic load}

It is known that the germicidal efficacy of sodium hypochlorite solution is lowered in the presence of organic materials because of a decrease in the $\mathrm{AC}$ concentration. Bloomfield et al. (1991) demonstrated that adding 0.5 and $1.0 \%(\mathrm{w} / \mathrm{v})$ albumin to a chlorine solution containing $250 \mathrm{mg} \mathrm{AC/L}$ reduced the killing of several bacteria from $>6$ log units to 0.3-1.9 log units and to $0.5-1.4 \log$ units, respectively. Takehara and Fukuzaki (2006) studied the decrease in the AC concentration $(100 \mathrm{mg} / \mathrm{L})$ in the presence of $0.3 \%$ $(\mathrm{w} / \mathrm{v})$ bovine serum albumin (BSA) over the $\mathrm{pH}$ range of 2 to 12 and found that the maximum decrease in AC concentration occurred at $\mathrm{pH}$ 9.5, whereas the minimum was observed at $\mathrm{pH}$ 4.5. This finding implies that $\mathrm{HOCl}$ which has the highest germicidal activity is less affected by the coexisting protein. It is of importance to note that $\mathrm{pH}$ values at which decomposition of $A C$ is promoted in the presence of protein are in agreement with the $\mathrm{pH}$ region (8.5 to 10) of sodium hypochlorite solutions at commonly used $\mathrm{AC}$ concentrations. 


\section{MECHANISM OF THE CLEANING ACTION}

It has been pointed out that the primary function of a detergent is to minimize the magnitude of attractive forces between soil and the solid surface by adsorption of detergent components both on soil and on the solid surface (Jennings, 1965). In addition, the decomposition of organic soil into low-molecular-weight fragments by detergents can accelerate the progress of cleaning. The cleaning action of sodium hypochlorite is based on the synergism of the oxidizing power of ${ }^{-} \mathrm{OCl}$ and the ability of ${ }^{-} \mathrm{OH}$ to dissolve organic soils.

\section{Role of ${ }^{-} \mathrm{OH}$}

Hydroxide ions in a concentrated sodium hypochlorite can dissolve a wide range of organic materials, i.e., proteins, polysaccharides, and fats. Sodium hydroxide is often added to sodium hypochlorite solution not only to strengthen the cleaning power, but also to stabilize free available chlorine in the form of ${ }^{-} \mathrm{OCl}$, and to reduce the corrosive effect of ${ }^{-} \mathrm{OCl}$ on metal. Hydroxide ions can be adsorbed both on most hydrophilic solid surfaces and on biopolyelectrolytes such as proteins (=desorption of $\mathrm{H}^{+}$), making their surfaces more negatively charged. As a result, ${ }^{-} \mathrm{OH}$ affects the interfacial properties of solid surfaces and soils in an aqueous solution, and their action is largely due to "surface-activity" (Koopal, 1985). In the case of reaction of $\mathrm{NaOH}$ and fat soils (i.e., saponification reaction), ${ }^{-} \mathrm{OH}$ degrades fats, transforming them into glycerol and sodium salts of carboxylic acids containing long chains of carbon atoms (soap), which in turn reduce the interfacial tension of the remaining fat-solution interfaces.

Figure 3 shows the effect of the $\mathrm{pH}$ of the cleaning solution on the removal efficiency of different kinds of proteins from stainless steel surfaces during batch cleaning (Takahashi et al., 2003b). Although BSA, $\beta$-lactoglobulin, casein, and gelatin have different properties, e.g., thermal stability, solubility, and molecular structure, there are no significant differences in the relationship between the removal efficiency and the $\mathrm{pH}$ among the four proteins. At $\mathrm{pHs}$ above 11, the removal efficiency increased markedly with increasing $\mathrm{pH}$. In the $\mathrm{pH}$ range of 4.0 to 9.0 , only small or no removal of proteins was observed. Although the amount of removed proteins increased slightly at a $\mathrm{pH}$ below 3.0, low-pH solutions often induce the aggregation of proteins, resulting in persistent residual soils. Thus, most naturally occurring proteins are susceptible to caustic alkali cleaning. It has also been reported that the rate of the removal of milk soils from the stainless steel surface is first-order with respect

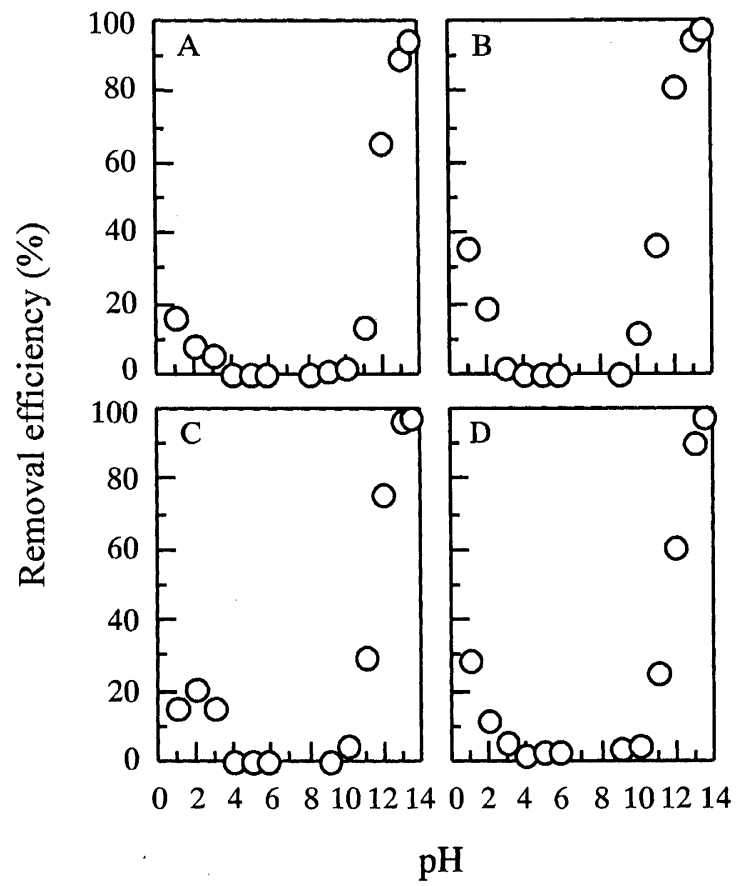

FIG. 3. Effect of the $\mathrm{pH}$ of the cleaning solution on the removal of BSA (A), $\beta$-lactoglobulin (B), casein (C), and gelatin (D) from stainless steel surfaces during batch cleaning at $40^{\circ} \mathrm{C}$. The $\mathrm{pH}$ values of cleaning solutions were adjusted to $\mathrm{pH} 1.0$ to 13.5 with $\mathrm{HNO}_{3}$ or $\mathrm{NaOH}$ solution.

to the ${ }^{-} \mathrm{OH}$ concentration in the range of 0.01 to $0.15 \mathrm{M}$ (Jennings, 1959). At high $\mathrm{pH}$ values, intramolecular electrostatic repulsion and the swelling of the proteins can be enhanced, and the adsorbed proteins become more soluble and dispersable in the $\mathrm{NaOH}$ solution. In addition, the repulsive force between proteins and stainless steel surfaces becomes greater, and attractive forces to hold protein molecule on stainless steel surfaces will diminish, thereby accelerating the removal of the adsorbed proteins. It is thought that preferential displacement by ${ }^{-} \mathrm{OH}$ ions is one of the principal cleaning mechanisms on hydrophilic solid surfaces (Fukuzaki et al., 2002; Takahashi and Fukuzaki, 2006).

In general, the rate of proteineous soil removal by $\mathrm{NaOH}$ solution is also enhanced with the increase in temperature. The combination of sodium hydroxide and heat stimulates the swelling of the soil layer and brings about the hydrolysis of proteins, thereby shortening lag time at the beginning of cleaning and accelerating the removal of proteins (Gra $\beta$ hoff, 1983, 1988; Jennings, 1959 and 1963; Takahashi et al., 2003a). Kinetic studies on the effect of temperature on the rate of removal of proteineous soils from stainless steel in $\mathrm{NaOH}$ cleaning showed that the first- 
order rate constant had an Arrhenius-type temperature dependence and increased by 1.4 to 1.6 times for every $10^{\circ} \mathrm{C}$ rise in temperature (Jennings, 1959 ; Takahashi and Fukuzaki, 2003).

\section{Role of ${ }^{-} \mathrm{OCI}$}

Which has the stronger cleaning power in a dilute sodium hypochlorite solution, $\mathrm{HOCl}$ or ${ }^{-} \mathrm{OCl}$ ? Recent investigations at the author's laboratory reveal that the ${ }^{-} \mathrm{OCl}$ concentration is a major factor determining the actual $A C$ concentration required for the removal of protein (BSA), acidic polysaccharide (pectin), and bacterial cells (Pseudomonas fluorescens) from hard solid surfaces $\left(\mathrm{Al}_{2} \mathrm{O}_{3}\right.$ surfaces) (Urano and Fukuzaki, 2005; Fukuzaki et al., 2006a). In the absence of $\mathrm{NaOCl}$, no significant desorption $(<10 \%)$ of $\mathrm{BSA}$, pectin, and $P$. fluorescens cells from $\mathrm{Al}_{2} \mathrm{O}_{3}$ surfaces occur over the $\mathrm{pH}$ range of 2 to 10 . In this $\mathrm{pH}$ region, their removal from $\mathrm{Al}_{2} \mathrm{O}_{3}$ surfaces occurs by the addition of $\mathrm{NaOCl}$, depending on the ${ }^{-} \mathrm{OCl}$ concentration. Figure 4 shows the efficiency of the removal of BSA, pectin, and $P$. fluorescens cells from $\mathrm{Al}_{2} \mathrm{O}_{3}$ surfaces, obtained at various $A C$ concentrations (100 to 2,000 $\mathrm{mg} / \mathrm{L}$ ) in the $\mathrm{pH}$ range of 2 to 10 , as a function of the - $\mathrm{OCl}$ concentration. These graphs clearly indicate that the removal of BSA, pectin, and $P$. fluorescens cells occurs in an ${ }^{-} \mathrm{OCl}$-dependent manner. At moderate ${ }^{-} \mathrm{OH}$ concentrations $(\mathrm{pH}>10),{ }^{-} \mathrm{OH}$ leads to the hydration and swelling of the adsorbed molecules of protein and pectin. This can facilitate the mass transfer of ${ }^{-} \mathrm{OCl}$ into the adsorbed layer toward the contact surfaces between the protein and solid sur- faces. It is also found that the first-order rate constants for BSA and pectin removal increase exponentially with the $-\mathrm{OCl}$ concentration (Urano and Fukuzaki, 2005). In these studies, it is indicated that no significant desorption, especially of BSA, takes place in the $\mathrm{pH}$ range of 1.5 to 6.5 even in the presence of the sufficient $A C$ concentration of 1,100 $\mathrm{mg} / \mathrm{L}$, indicating that undissociated $\mathrm{HOCl}$ exerted little action in the removal of these organic soils.

As to the removal of BSA, the primary function of $\mathrm{OCl}$ is to decompose the BSA molecules into lowmolecular-weight fragments by its oxidative action (Urano and Fukuzaki, 2005). The chlorination reactions of proteins with $-\mathrm{OCl}$ occur mainly on the free amino groups of amino acid residues to give chloramines under physiological conditions (Clark et al., 1986; Domigan et al., 1995). Hawkins and Davies (1998 and 1999) have reported that free amino groups of lysine residues, which are present in many proteins at a much higher level than other reactive residues, were converted into unstable chloramines via the reaction with $\mathrm{HOCl}^{-} \mathrm{OCl}$, which were in turn broken down into nitrogen-centered radicals via the homolysis of $\mathrm{N}-\mathrm{Cl}$ bonds. They concluded that the chloramine formation and nitrogen-centered radicals are key species involved in the $\mathrm{HOCl} /{ }^{-} \mathrm{OCl}$-induced backbone fragmentation of proteins. On the other hand, despite little occurrence of the decomposition of pectin and $P$. fluorescens cells, their removal can be enhanced in the presence of ${ }^{-} \mathrm{OCl}$. Conceivably, - $\mathrm{OCl}$ might also attack the pectin- $\mathrm{Al}_{2} \mathrm{O}_{3}$ and cell$\mathrm{Al}_{2} \mathrm{O}_{3}$ interfaces and partially displace or cleave ad-
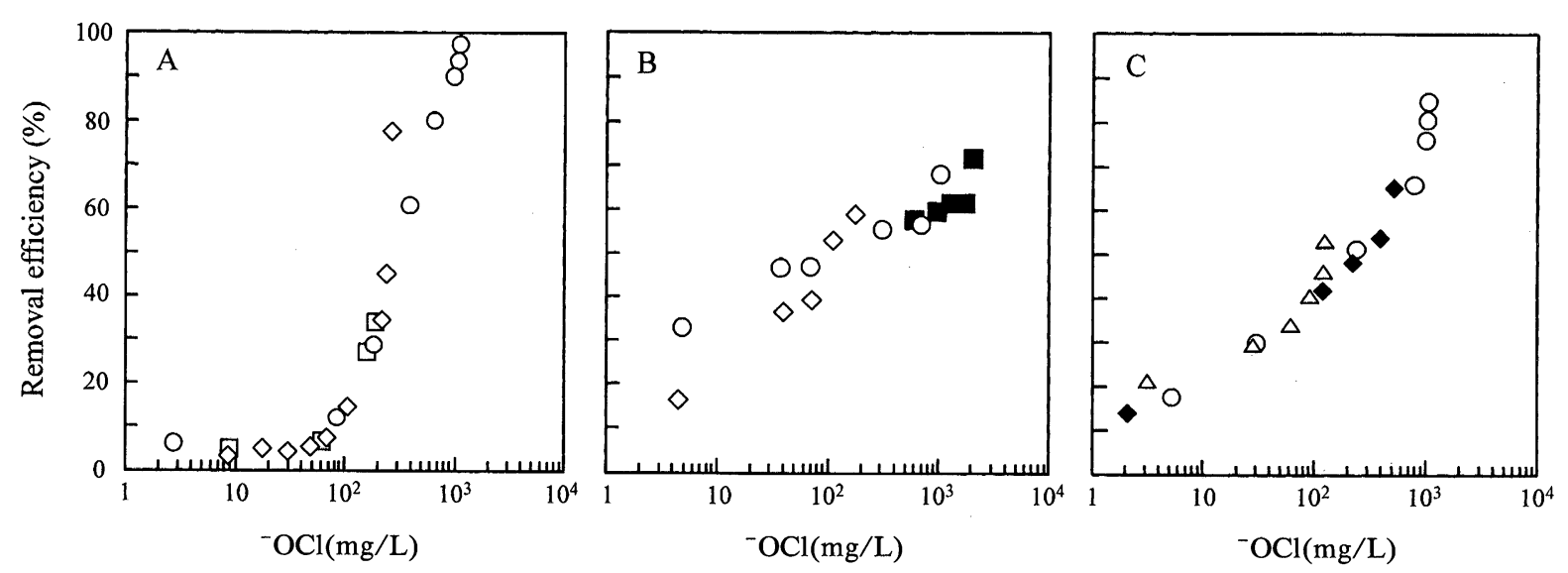

FIG. 4. Removal of $\mathrm{BSA}(\mathrm{A})$, pectin (B), and $P$. fluorescens cells (C) from $\mathrm{Al}_{2} \mathrm{O}_{3}$ surfaces as a function of the - $\mathrm{OCl}$ concentration (batch cleaning at $40^{\circ} \mathrm{C}$ ). Cleaning experiments were conducted at total $\mathrm{AC}$ concentrations of 120 to $2200 \mathrm{mg} / \mathrm{L}$ at various $\mathrm{pH}$ values. The data obtained in the $\mathrm{pH}$ range of 2 to 10 , where no significant desorption occurred by the action of ${ }^{-} \mathrm{OH}$ alone, were plotted against the ${ }^{-} \mathrm{OCl}$ concentration. Symbols (total $\mathrm{AC}$ concentration used in experiment, mg/L): $\triangle, 120 \mathrm{mg} / \mathrm{L} ; \square, 200 \mathrm{mg} / \mathrm{L} ; \diamond, 250 \mathrm{mg} / \mathrm{L} ;>, 500 \mathrm{mg} / \mathrm{L} ; \bigcirc, 1000$ or $1100 \mathrm{mg} / \mathrm{L}$; $2200 \mathrm{mg} / \mathrm{L}$. 
sorbing groups on pectin molecules and the bacterial cells. At present, the mode of action of ${ }^{-} \mathrm{OCl}$ at solidliquid interfaces has not been fully elucidated and a study on this mechanism is in progress at the author's laboratory.

The findings in Fig. 3 indicate that ${ }^{-} \mathrm{OCl}$ is available for the removal of biofilm. Biofilm consists of both microbes and the extracellular polymeric substances (EPS), composed of (acidic) polysaccharides or globular glycoproreins (Costerton et al., 1981). In the early stage of biofilm formation, bacteria along with organic and inorganic molecules, e.g., proteins and polysaccharides, are adsorbed on a solid surface forming a conditioning film. The conditioning film alters the physicochemical properties of the solid surface which may also induce the subsequent adhesion of microbial cells. The attached microbes grow and produce EPS that contribute to the anchorage of the cells to the surface and serve to protect microbes from hostile environments. Biofilm bacteria grown on various solid surfaces are 150 to 3,000 times more resistant to $\mathrm{HOCl}(\mathrm{pH} 7)$ than are unattached cells (LeChevallier et al., 1988). To prevent microbes from forming biofilm, it is necessary to eliminate as much as possible both the conditioning film and EPS. In this regard, the repeated use of alkaline hypochlorite solution ( ${ }^{-} \mathrm{OCl}$ ) and weak acidic hypochlorite solution $(\mathrm{HOCl})$ is expected to be effective for the successful control of biofilm.

At the $\mathrm{pH}$ region above $12,{ }^{-} \mathrm{OCl}$ and ${ }^{-} \mathrm{OH}$ can synergistically enhance the efficiency and the rate of the removal of, especially, protein. Besides the preferential displacement by ${ }^{-} \mathrm{OH}$, high concentrations of $-\mathrm{OH}$ cause the deprotonation of the $\mathrm{N}$ atom involved in the peptide bond, resulting in the increase in the electron density of the $\mathrm{N}$ atom. As a result, the peptide bond becomes more susceptible to the electophilic attack of $\mathrm{Cl}^{+}$, thereby accelerating the fragmentation of the protein molecule. In caustic alkali cleaning at the ${ }^{-} \mathrm{OCl}$ concentration of $\mathrm{ca} \cdot 1,000$ $\mathrm{mg} / \mathrm{L}$, the first-order rate constant for BSA desorption increases by approximately 5 times by increasing $\mathrm{pH}$ values from 10 to 12.5 (Urano and Fukuzaki, unpublished data).

\section{ELECTROLYZED WATER AND WEAK ACIDIC HYPOCHLORITE SOLUTION}

Recently, electrolyzed water has been receiving attention as a novel and alternative disinfectant to sodium hypochlorite solution. When sodium chloride $(\mathrm{NaCl})$ solution is electrolyzed using an electrolyzer in which the anode and cathode are separated by a membrane, acidic electrolyzed water $(\mathrm{pH} 2$ to 3$)$ is generated at the anode site, while alkaline electrolyzed water ( $\mathrm{pH} 11$ to 12$)$ is generated at the cathode site. In the case of non-membrane electrolyzer, electrolysis of the $\mathrm{NaCl}$ solution provides weak alkaline electrolyzed water containing sodium hypochlorite $(\mathrm{pH}>7.5)$, which is chemically identical with a dilute $\mathrm{NaOCl}$ solution. Weak acidic electrolyzed water ( $\mathrm{pH} 5$ to 6.5 ) is produced by the electrolysis of a diluted hydrochloric acid $(\mathrm{HCl})$ in nonmembrane electrolyzer, followed by dilution with water. Weak acidic hypochlorite solution is commercially and mechanically prepared by addition of $\mathrm{HCl}$ to a diluted sodium hypochlorite solution. In manual preparation, acetic acid is the most suitable and safest acid for the preparation of an acidic hypochlorite solution (Kuroiwa et al., 2003). Aside from the way it is produced, weak acidic hypochlorite solution prepared by using $\mathrm{HCl}$ is chemically identical with weak acidic electrolyzed water.

Acidic electrolyzed water and weak acidic hypochlorite solution have been demonstrated to have a bactericidal effect on fresh-cut vegetables (Izumi, 1999; Koseki and Itoh, 2001; Koseki et al., 2001; Parish, 2003). The bactericidal activity of electrolyzed water can be also explained by the chemical equilibrium of $\mathrm{Cl}_{2}, \mathrm{HOCl}$, and ${ }^{-} \mathrm{OCl}$ as mentioned above. Len et al. (2000) have studied the inactivation of Bacillus cereus in $30 \mathrm{sec}$ exposure to electrolyzed water (10 to $12 \mathrm{mg} \mathrm{AC/L}$ ) adjusted to a $\mathrm{pH}$ in the range of 2 to 9 and reported that more than a 100-fold reduction was observed in the $\mathrm{pH}$ range of 2 to 6 . They also demonstrated that the maximum bactericidal activity of electrolyzed water occurred at the $\mathrm{pH}$ region between 4 and 6 where $\mathrm{HOCl}$ concentration is the highest, indicating that $\mathrm{HOCl}$ is the primary component for inactivation. Note that weak acidic electrolyzed water and hypochlorite solution have a poor ability to remove microbial cells and organic soils from solid surfaces (see Fig. 4).

Weak acidic hypochlorite solution is commonly used in the concentration range of 50 to $200 \mathrm{mg} / \mathrm{L}$ with the contact time of 1 to 2 min to disinfect surfaces of fresh and fresh-cut produce, and of processing equipment (Parish, 2003). Although the germicidal activity of hypochlorite solution becomes the highest at $\mathrm{pHs}$ between 4 and $6, \mathrm{pH}$ values between 6 and 7 are typically used to the minimize the corrosion of metals while yielding acceptable chlorine efficacy.

Alkaline electrolyzed water is considered to be a dilute sodium hydroxide solution and it is useful for the removal of organic soils on solid surfaces (Fukuzaki, et al., 2004; Takehara et al., 2001) and hence also for preliminary cleaning before a disinfecting operation 
with acidic electrolyzed water (Koseki et al., 2001; Yoshida, et al., 2005).

\section{COMBINED USE OF SODIUM HYPHOCHLORITTE AND A SURFACTANT}

The high surface tension $(\gamma)$ is one of disadvantages of sodium hypochlorite from the viewpoints of cleaning and disinfecting operations (Table 1). This is just a weak point of water in terms of the wettability. When $\mathrm{NaOCl}$ or $\mathrm{NaOH}$ is added to water, the $\gamma$ value undergoes a slow but regular increase. The $y$ values of the $\mathrm{NaOH}$ solution and $\mathrm{NaOCl}$ solution of $\mathrm{pH} 12$ are 71 to $73 \mathrm{mN} / \mathrm{m}$ at $20^{\circ} \mathrm{C}$. The property of high $\gamma$ prevents the $\mathrm{NaOCl}$ solution from wetting solid surfaces and soils, and from penetrating into the deposited soil layer. Surface-active agents (surfactants) are regarded as substances capable of reducing surface (interfacial) tension. The addition of only 0.01 to $0.1 \%$ of a surfactant makes the $\gamma$ values of $\mathrm{NaOCl}$ and $\mathrm{NaOH}$ solution lower to approximately 29 to $35 \mathrm{mN} / \mathrm{m}$. The marked decrease in the $\gamma$ of $\mathrm{NaOH}$ and $\mathrm{NaOCl}$ solutions in the presence of a surfactant results in the improvement of the wetting ability of the solutions. Outer rinds and waxy cuticle on the surface of many fruits and vegetables, and polymer surfaces are hydrophobic in character and hence they show poor wettability to water-based cleaning or disinfecting solutions. Surfactants can improve the wettability of hydrophobic surfaces to water, thereby augmenting the efficiency of cleaning or disinfection. Ono et al. (2005) demonstrated that 2.5- to 2.8-logunit reduction in vegetative bacteria on cucumbers and long green onions could be achieved reliably by the combined use of weak acidic hypochlorite solution ( $\mathrm{pH} \mathrm{6,} 100 \mathrm{mg} \mathrm{AC/L}$ ) and a nonionic surfactant (food-emulsifying agent, $0.025 \%[\mathrm{w} / \mathrm{v}]$ ) for $1 \mathrm{~min}$, in comparison to 0.8- to 1.6-log-unit reduction by weak acidic hypochlorite solution alone. The addition of a nonionic surfactant $(0.02 \%, \mathrm{w} / \mathrm{v})$ to $\mathrm{NaOH}$ solution ( $\mathrm{pH} 12$ ) could improve the efficiency of the cleaning of hydrophobic polyethylene terephthalate (PET) surfaces fouled with protein and catechin (Fukuzaki et al., 2006b). This indicates that the principal point of the working of ${ }^{-} \mathrm{OH}$ ions is the soil-PET interfaces rather than soil-liquid interfaces.

The technique of foam cleaning, combining surfactants, water, and compressed air, has been applying increasingly in the food industry. The use of alkaline $\mathrm{NaOCl}$ solution as the ingredient of foam cleaning is more suitable for the removal of organic soils and microbes even though the $\mathrm{AC}$ concentration and $\mathrm{pH}$ of $\mathrm{NaOCl}$ solution are relatively low (e.g. $200 \mathrm{mg} \mathrm{AC/L}$ at $\mathrm{pH}$ 10). Foam cleaning has many advantages, e.g., of lowering the interfacial tension, prolonging the contact time between detergents and soils to loosen all soils from equipment surfaces, low mechanical action, reducing the amount of detergent, and applicability to horizontal, vertical, and inverted surfaces, and to the parts of the machinery not accessible to human hands. Foam can suck up soils released from solid surfaces, which in turn makes rinsing easier.

\section{FINAL REMARKS}

To utilize sodium hypochlorite, electrolyzed water, and weak acidic hypochlorite solution effectively, it is important that we should thoroughly know the basic property of each solution and should utilize each excellent function correctly. It is especially necessary to make it clear whether the objective is "cleaning" or "disinfecting". Entirely removing organic soils is an important pretreatment step to perform disinfection efficiently. It is indispensable that we use $\mathrm{pH}$ preparations and surfactants effectively to complement or to strengthen the cleaning and disinfecting actions of sodium hypochlorite solution. The findings presented here provide useful information concerning the cleaning and disinfecting operations using $\mathrm{NaOCl}$ solution. At present, the research into and development of alternative cleaning agents and disinfectants to chlorine has continued to progress. However, despite the introduction of new cleaning agents and disinfectants, sodium hypochlorite solution is likely to continue to find wide use in food industry settings because of its numerous advantages.

\section{REFERENCES}

Adam, L. C., Fábián, I., Suzuki, K., and Gordon G. (1992) Hypochlorous acid decomposition in the $\mathrm{pH}$ 5-8 region. Inorg., Chem., 31, 3534-3541.

Albrich, J. M., McCarthy, C. A., and Hurst, J. (1981) Biological reactivity of hypochlorous acid: implications for microbicidal mechanisms of leukocyte myeloperoxidase. Proc. Natl. Acad. Sci. USA, 78, 210-214.

Barrette, W. C. Jr., Albrich, J. M., and Hurst, J. K. (1987) Hypochlorous acid-promoted loss of metabolic energy in Escherichia coli. Infect. Immun, 55, 2518-2525.

Barrette, W. C. Jr., Hannum, D. M., Wheeler, W. D., and Hurst, J. K. (1989) General mechanism for the bacterial toxicity of hypochlorous acid: abolition of ATP production. Biochemistry, 28, 9172-9178.

Bloomfield, S. F., Arthur, M., Looney, E., Begum, K., and Patel, H. (1991) Comparative testing of disinfectant and antiseptic products using proposed European suspension testing methods. Lett. Appl. Microbiol., 13, 233-237.

Brazis, A. R., Leslie, J. E., Kabler, P. W., and Woodward, R. L. (1958) The inactivation of spores of Bacillus globigii and Bacillus anthracis by free available chlorine. Appl. Microbiol., 6, 338-342. 
Charlton, D. B., and Levine, M. (1935) Some observations on the germicidal efficiency of chloramines- $T$ and calcium hypochlorite. J. Bacteriol., 30, 163-171.

Champer, A. K., and McFeters, G. A. (1979) Chlorine injury and the enumeration of waterborne coliform bacteria. Appl. Environ. Microbial., 37, 633-641.

Chick, H. (1908) An investigation of the laws of disinfection. J. Hyg., 8, 92-158.

Clark R. A., Szot, S., Williams, M. A., and Kagan, H. M. (1986) Oxidation of lysine side-chains of elastin by the myeloperoxidase system and by stimulated human neutrophils. Biochem. Biophys. Res. Commun. 135, 451457

Coates, D. and Death, J. E. (1978) Sporicidal activity of mixtures of alcohol and hypochlorites. J. Clin. Pathol., 31, 148-152.

Costerton, J. W., Irvin, R. T., and Chen, K.-J. (1981) The bacterial glycocalyx in nature and disease. Ann. Rev. Microbiol., 35, 299-324.

Cousins, C. M., and Allan, C. D. (1967) Sporicidal properties of some halogens. J. Appl. Bacteriol., 30, 168-174.

Dantec, C. L., Duguet, J.-P., Montiel, A., Dumoutier, N., Dubrou, S., and Vincent, V. (2002) Chlorine disinfection of atypical Mycobacteria isolated from a water distribution system. Appl. Environ. Microbiol., 68, 1025-1032.

Death, J. E., and Coates, D. (1979) Effect of $\mathrm{pH}$ on sporicidal and microbicidal activity of buffered mixtures of alcohol and sodium hypochlorite. J. Clin. Pathol., 32, 148-153.

Domigan, N. M., Charlton, T. S., Duncan, M. W., Winterbourn, C. C., and Kettle, A. J. (1995) Chlorination of tyrosyl residues in peptides by myeloperoxidase and human neutruphils. J. Biol. Chem., 270, 16542-16548.

Dukan, S., Belkin, S., and Touati, D. (1999) Reactive oxygen species are partially involved in the bacteriocidal action of hypochlorous acid. Arch. Biochem. Biophys., 367, 311-316.

Dunkan, S., and Touati, D. (1996) Hypochlorous acid stress in Escherichia coli: resistance, DNA damage, and comparison with hydrogen peroxide stress. J. Bacteriol., 178, 6145-6150.

Estrela, C., Estrela, C. R. A., Barbin, E. L., Spanó, J. C., Marchesan, M. A., and Pécora, J. D. (2002) Braz. Dent. J., 13, 113-117.

Folkes, L. K., Candeias, L. P., and Wardman, P. (1995) Kinetics and mechanisms of hypochlorous acid reactions. Arch. Biochem. Biophys., 323, 120-126.

Fukuzaki, S., Nishio, N., Shobayashi, M., and Nagai, S. (1990) Appl. Environ. Microbiol., 56, 719-723.

Fukuzaki, S., Urano, H., and Nagata, K. (2002) Detergency effect of trisodium phosphate on the removal of bovine serum albumin from alumina surfaces during caustic alkali cleaning. Biocontrol Sci., 7, 139-146.

Fukuzaki, S., Hiratsuka, H., Takehara, A., Takahashi, K., and Sasaki, K. (2004) Efficacy of electrolyzed water as a primary cleaning agent. Biocontrol Sci., 9, 105-109.

Fukuzaki, S., Urano, H., and Yamada S. (2006a) Mechanism of the removal of adhered bacterial cells by cleaning with sodium hypochlorite. Current Adv. Mater. Processes, 18, 1044-1045 (in Japanese).

Fukuzaki, S., Takehara, A., and Takahashi, K. (2006b) Role of a surfactant in caustic alkali cleaning of polyethylene terephthalate surfaces fouled with organic substances. Biocontrol Sci., 11, 167-174.

Graßhoff, A. (1983) The influence of chemical components of caustic cleaners on incrusted milk deposits removal kinetics. Kiel. Milchwirtsch. Forschungsber., 35, 493-519.

Graßhoff, A. (1988) The influence of chemical components of caustic cleaners on incrusted milk deposits removal kinetics. Kiel. Milchwirtsch. Forschungsber., 40, 139-177.

Hazell, L. J., and Stocker, R. (1993) Oxidation of lowdensity lipoprotein with hypochlorite causes transformation of the lipoprotein into a high-uptake form for macrophages. Biochem. J., 290, 165-172.

Hazell, L. J., van den Berg, J. J., and Stocker, R. (1994) Oxidation of low-density lipoprotein by hypochlorite causes aggregation that is mediated by modification of lysine residues rather than lipid oxidation. Biochem. J., 302, 297-304

Hawkins, C. L., and Davies, M. J. (1998) Hypochloriteinduced damage to proteins: formation of nitrogencentred radicals from lysine residues and their role in protein fragmentation. Biochem. J., 332, 617-625.

Hawkins, C. L., and Davies, M. J. (1999) Hypochloriteinduced oxidation of proteins in plasma: formation of chloramines and nitrogen-centred radicals and their role in protein fragmentation. Biochem. J., 340, 539-548.

Heinecke, J., Li, W., Daehnke, H., and Goldstein, J. (1993) Dityrosine, a specific marker of oxidation, is synthesized by the myeloperoxidase-hydrogen peroxide system of human neutrophils and macrophages. J. Biol. Chem., 268, 4069-4077.

Herrero, A. A., Gomez, R. F., Snedecor, B., Tolman, C. J., and Roberts, M. F. (1985) Growth inhibition of Clostridium thermocellum by carboxylic acids: a mechanism based on uncoupling by weak acids. Appl. Microbiol. Biotechnol., 22, 53-62.

Iwasawa, A., Nakamura, R., Inoue, K., Tanba, T., and Nishimoto, Y. (2004) The influence of $\mathrm{pH}$ and salt concentrations on the bactericidal effects of strong acidic electrolyzed water. Bokin Bobai, 32, 301- 306.

Izumi, H. (1999) Electrolyzed water as a disinfectant for fresh-cut vegetables. J. Food Sci., 64, 536-539.

Jennings, W. G. (1959) Circulation cleaning III. The kinetics of a simple detergent system. J. Dairy Sci., 42, 17631771.

Jennings, W. G. (1965) Theory and practice of hardsurface cleaning. In Advances in Food Research, Vol. 14 (Chichester, C. O. and Mark, E. M., eds.), pp. 325-458, Academic Press, New York.

Koopal, L. K. (1985) Physico-chemical aspects of hardsurface cleaning. 1. Soil removal mechanisms. Neth. Milk Dairy J., 39, 127-154.

Koseki, S., and Itoh, K. (2001) Prediction of microbial growth in fresh-cut vegetables treated with acidic electrolyzed water during storage under various temperature conditions. J. Food Prot., 64, 1935-1942.

Koseki, S., Yoshida, K., Isobe, S., and Itoh, K. (2001) Decontamination of lettuce using acidic electrolyzed water. J. Food Prot., 64, 652-658.

Kuroiwa, K., Nakayama, H., Kuwahara, T., Tamagawa, K., Hattori, K., Murakami, K., Korai, H., and Ohnishi, Y. (2003) Augmenting effect of acetic acid for acidification on bactericidal activity of hypochlorite solution. Lett. Appl., Microbiol., 36, 46-49.

LeChevallier, M. W., Cawthon, C. D., and Lee, R. G. (1988) Inactivation of biofilm bacteria. Appl. Environ. Microbiol. 54, 2492-2499.

Len, S.-V., Hung, Y.-C., Erickson, M., and Kim, C. (2000) Ultraviolet spectrophotometric characterization and bactericidal properties of electrolyzed oxidizing water as influenced by amperage and $\mathrm{pH}$. J. Food Prot., 63, 1534- 
1537.

McKenna, S. M., and Davies, K. J. A. (1988) The inhibition of bacterial growth by hypochlorous acid: possible role in the bactericidal activity of phagocytes. Biochem. J., 254, 685-692.

Morris, J. C. (1966a) The acid ionization constant of $\mathrm{HOCl}$ from 5 to $35^{\circ}$. J. Phys. Chem., 70, 3798-3805.

Morris, J. C. (1966b) Failure of chlorination. J. Am. Water Assoc., 58, 1475-1482.

Nebel, C. (1981) Ozone treatment of potable water-part I, Public works, 112, 86-90.

Nightingale, Z. D., Lancha, Jr., A. H., Handelman, S. K., Dolnikowski, G. G., Busse, S. C., Dratz, E. A., Blumberg, J. B., and Handelman, G. J. (2000) Relative reactivity of lysine and other peptide-bound amino acids to oxidation by hypochlorite. Free Radic. Biol. Med., 29, 425-433.

Ono, T., Miyake, M., and Yamashita, K. (2005) Disinfection effect on vegetables by weak acid hypochlorous water to which a nonionic surfactant was added. Bokin Bobai, 33 257-262.

Page, M. A. (2003) Strategies for integrated control of biological agents by small utilities. University of Illinois, Thesis.

Parish, M., Beuchat, L., Suslow, T., Harris, L., Garrett, E., Farber, J., and Busta, F. (2003) Methods to reduce/ eliminate pathogens from fresh and fresh-cut produce. Comp. Rev. Food Sci. Food Safety, 2, 161-173.

Pereira, W. E., Hoyano, Y., Summons, R. E., Bacon, V. M., and Duffield, A. M. (1973) The reaction of aqueous hypochlorous acid with amino acids and dipeptides. Biochim. Biophys. Acta., 313, 170-180.

Prutz, W. A. (1998) Interactions of hypochlorous acid with pyrimidine nucleotides, and secondary reactions of chlorinated pyrimidines with GSH, NADH, and other substrates. Arch. Biochem. Biophys., 349, 183-191

Rosen, H., and Klebanoff, S. (1982) Oxidation of Esherichia coli iron centers by the myeloperoxidasemediated microbiocidal system. J. Biol. Chem., 257, $13731-13735$.

Russel, A. D. (1990) Bacterial spore and chemical sporicidal agents. Clin. Microbiol. Rev., 3, 99-119.

Rutala, W. A., and Weber, D. J. (1997) Uses of inorganic hypochlorite (bleach) in health-care facilities. Clin. Microbiol. Rev., 10, 597-610.

Sagripanti, J.-L., and Bonifacino, A. (1996) Comparative sporicidal effects of liquid chemical agants. Appl. Environ. Microbiol., 62, 545-551.

Siqueira, E. L. (2000) Chemical stability of $0.5 \%$ sodium hypochlorite solutions. ECLER Endod., 2, 1-39. Sao Paulo.

Spickett, C. M., Jerlich, A., Panasenko, O. M., Arnhold, J., Pitt, A. R., Stelmaszynska, T., and Schaur R. J., (2000) The reactions of hypochlorous acid, the reactive oxygen species produced by myeloperoxidase, with lipids. Acta.
Biochimica. Polonica., 47, 889-899.

Takahashi, K., Koike, K., and Fukuzaki, S. (2003a) Comparison of the efficacies of gaseous ozone and sodium hypochlorite in cleaning stainless steel particles fouled with proteins. Biocontrol Sci., 8, 87-91.

Takahashi, K., Koike, K., and S. Fukuzaki (2003b) Effects of $\mathrm{pH}$, temperature, and oxidizing agents on desorption of proteins from stainless steel surfaces. Report Ind. Technol. Ctr. Okayama Pref., 29, 36-39 (in Japanese).

Takahashi, K., and S. Fukuzaki (2003) Kinetic approach to the nonlinear curve of bovine serum albumin desorption from stainless steel surfaces. Biocontro/ Sci., 8, 111-117.

Takahashi, K., and Fukuzaki, S. (2006) Cleanability of stainless steel surfaces as influenced by heat treatment. Biocontrol Sci., 11, 61-68.

Takehara, A., Urano, H., and Fukuzaki, S. (2001) Cleaning of alumina fouled with bovine serum albumin by the combined use of gaseous ozone and alkaline electrolyzed water. Biocontrol Sci., 6, 103-106.

Takehara, A., and Fukuzaki, S. (2006) Relationship between the $\mathrm{pH}$ and decrease in available chlorine of sodium hypochlorite in the presence of organic compounds or during freezing treatment. Report of Ind. Technol. Ctr. Okayama Pref., 32, 10-13 (in Japanese).

Thomas, E. L. (1979) Myeloperoxidase-hydrogen peroxidechloride antimicrobial system: effect of exogenous amines on antibacterial action against Escherichia coli. Infect. Immun., 25, 110-116.

Urano, H., and Fukuzaki, S. (2005) The mode of action of sodium hypochlorite in the cleaning process. Biocontrol Sci., 10, 21-29.

Watson, H. E. (1908) A note on the variation of the rate of disinfection with change in the concentration of the disinfectant. J. Hyg., 8, 536.

Winterbourn, C. C., and Brennan, S. O. (1997) Characterization of the oxidation products of the reaction between reduced glutathione and hypochlorous acid. Biochem. J., 326, 87-92

Weast, R. C. (1988) CRC handbook of chemistry and physics, $1^{\text {st }}$ student edition, CRC Press Inc., Boca Raton, Florida.

Wojtowicz, J. A. (1979) Chlorine oxygen acids and salts: chlorine monoxide, hypochlorous acid and hypochlorites. In Kirk-Othmer Encyclopedia of Chemical Technology, vol. 5, 3rd ed. (Mark, H. F., Othmer, D. F., Overberger, C. G., Seaborg, G. T., and Grayson, M. eds.), pp. 580-611, John Wiley \& Sons, New York.

Yoshida, K., Achiwa, N., Katayose, M., Kizawa, Y., Koseki, S., Isobe, S., and Abe, K. (2005) Decontamination of precut green onion using electrolyzed water and observations of its surface by confocal scanning laser microscope. J. Jpn. Soc. Food Sci. Technol., 52, 266272. 